JMI Vol. 42 No. 1, Juni 2020

METAL INDONESIA

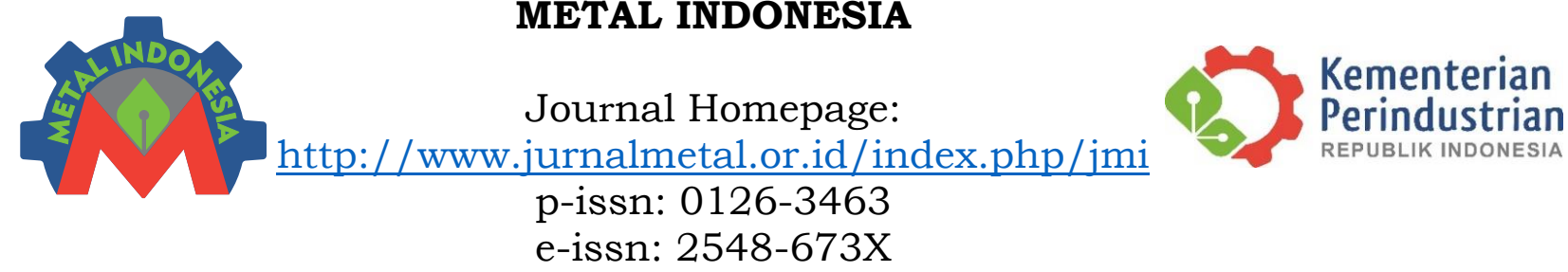

\title{
STUDI PENGARUH PADUAN Cr/Mo DENGAN WAKTU PERENDAMAN CRYOGENIC TREATMENT TERHADAP SIFAT KERAS, TANGGUH, TAHAN ABRASIF, DAN STRUKTUR MIKRO BAJA Ni BERBASIS LATERIT
}

\section{STUDY OF Cr/Mo ALLOYS LATERITIC STEEL WITH THE SOAKING TIME CRYOGENIC TREATMENT ON HARDNESS, TOUGHNESS, ABRASIVE RESISTANT, AND MICROSTRUCTURE}

\author{
Alfa Sendya Hayu Marzuki ${ }^{1}$, Satrio Herbirowo*2, Bintang Adjiantoro ${ }^{2}$, Septian Adi Chandra ${ }^{2}$, Yeni \\ Muriani Zulaida ${ }^{1}$, Efendi Mabruri ${ }^{2}$ \\ ${ }^{1}$ Teknik Metalurgi, Fakultas Teknik, Universitas Sultan Ageng Tirtayasa \\ Jl. Jenderal Sudirman Km 3 Cilegon, Banten 42435, Indonesia \\ ${ }^{2}$ Pusat Penelitian Metalurgi dan Material - LIPI \\ Gedung 470 Kawasan Puspiptek, Serpong, Tangerang Selatan, Indonesia \\ E-mail : ${ }^{2}$ satr006@lipi.go.id \\ *Kontributor Utama
}

\begin{abstract}
Abstrak
Grinding ball merupakan salah satu komponen dari industri tambang dan pengolahan mineral yang mempengaruhi biaya produksi. Kebutuhan grinding ball dalam negeri saat ini masih bergantung pada produk impor. Pemilihan baja berbasis laterit karena cadangan laterit di Indonesia sangat melimpah, selain itu baja laterit sudah memiliki kandungan nikel dimana unsur paduan tersebut baik untuk meningkatkan kekerasan yang dibutuhkan pada grinding ball. Namun tingkat kekerasan baja berbasis laterit yang digunakan pada penelitian ini belum memiliki nilai yang cukup untuk digunakan sebagai material grinding ball. Oleh karena itu, pada penelitian ini dilakukan proses cryogenic treatment dengan variasi waktu perendaman 10, 60, dan 360 menit serta menggunakan perbedaan komposisi paduan Cr dan Mo kemudian dilakukan pengujian kekerasan, ketahanan aus, ketangguhan dan analisis struktur mikro. Berdasarkan hasil yang diperoleh menunjukkan bahwa kekerasan setelah perlakuan mengalami peningkatan signifikan dari 17 menjadi 33,55 HRC. Selain itu, ketahanan abrasif setelah perlakuan juga meningkat seiring dengan penambahan waktu perendaman dari 0,000603 menjadi $0,000475 \mathrm{mg} / \mathrm{cm}^{2}$.putaran. Peningkatan tersebut terjadi karena adanya peningkatan persentase martensit pada sampel. Nilai kekerasan dan ketahanan aus terbaik terdapat pada sampel dengan paduan CrMo pada waktu perendaman 360 menit yaitu 44,1 HRC dan $0,000475 \mathrm{mg} / \mathrm{cm}^{2}$.putaran. Sehingga pada penelitian ini menunjukkan bahwa waktu perendaman cryogenic treatment dan komposisi paduan $\mathrm{Cr}$ dan Mo berpengaruh terhadap kekerasan, ketahanan abrasif serta ketangguhan baja nikel berbasis laterit.
\end{abstract}

Kata Kunci: Baja nikel laterit, cryogenic treatment, kekerasan, ketahanan abrasif, ketangguhan 


\begin{abstract}
Grinding ball is a component of the mining and mineral processing industry that affects production costs. Grinding ball needs in Indonesia still depend on imported products. Laterite-based steel is chosen because of the resource of laterite in Indonesia are very abundant, besides laterite steel has nickel content which is great for increasing the hardness that needed in grinding ball. However, the hardness of Ni laterite steel used in this study does not have enough hardness to be used as a grinding ball material. Therefore, in this study cryogenic treatment was carried out with variations in soaking time during 10, 60 and 360 minutes and also using differences in the alloying composition of $\mathrm{Cr} / \mathrm{Mo}$ then performed characterization of hardness, abrasive resistance, toughness and microstructure analysis. Based on the results obtained showed that hardness after treatment increases with increasing soaking time from 17 to 33,55 HRC significantly. In addition, abrasive resistance after treatment also increases with increasing soaking time from 0,000603 to $0,000475 \mathrm{mg} / \mathrm{cm} 2$.cycle. This increase occurred because of an increase in the percentage of the martensite phase in the sample. The optimum value of hardness and wear resistance is found in samples with CrMo alloy at 360 minutes soaking time, which is $44.1 \mathrm{HRC}$ and $0.000475 \mathrm{mg} / \mathrm{cm} 2 \cdot \mathrm{cycle}$. This study shows that cryogenic treatment soaking time and $\mathrm{Cr}$ and Mo alloy composition affect the hardness, abrasive resistance, and toughness of laterite nickel-based steel.
\end{abstract}

Keyword: Nickel laterite steel, cryogenic treatment, hardness, abrasive resistance, toughness

\section{PENDAHULUAN}

Pada industri tambang dan pengolahan mineral, terdapat masalah utama yang mempengaruhi biaya produksi, yaitu konsumsi energi dan keausan. Grinding ball merupakan komponen penting yaitu pada proses kominusi. Pada saat beroperasi, grinding ball akan mengalami benturan dan gesekan dengan bijih yang dikominusi sehingga grinding ball sangat rentan terhadap keausan dan dibutuhkan grinding ball dengan ketahanan abrasif yang tinggi untuk menjaga efektifitas kerja dan meningkatkan umur pakai grinding ball (Sabih et. al, 2017). Kebutuhan grinding ball dalam negeri saat ini masih bergantung pada produk impor dan cenderung semakin meningkat seiring dengan meningkatnya proses milling khususnya industri pertambangan dan mineral (Herbirowo dan Adjiantoro 2016). Baja yang digunakan pada penelitian ini adalah baja Ni yang merupakan baja karbon yang dibuat dengan bahan baku dasar bijih laterit yang digolongkan sebagai low alloy steel dengan paduan utama yaitu nikel dan beberapa unsur paduan lain. Baja tersebut belum memenuhi standar kekerasan untuk digunakan sebagai grinding ball menurut Standar Nasional Indonesia (SNI-1069) yaitu 47 HRC sedangkan nilai kekerasan baja hasil penambahan kromium dan molibdenum hanya berkisar 28-34 HRC.

Salah satu perlakuan pengerasan suatu logam yang cukup dikenal yaitu cryogenic treatment. Cryogenic treatment merupakan perlakuan panas pada baja yang melibatkan perendaman pada temperatur sub-zero pada selang waktu tertentu kemudian dipanaskan kembali pada temperatur ruang dan dilanjutkan dengan pemanasan (tempering) selama 1 hingga 2 jam. Cryogenic treatment merupakan perlakuan yang diberikan pada baja dengan tujuan untuk menghilangkan retained austenite yang terbentuk setelah proses perlakuan panas konvensional sehingga akan dihasilkan baja dengan struktur mikro martensit dengan persentase austenit sisa yang lebih rendah sehingga akan mendapatkan baja dengan kekerasan dan ketahanan aus yang lebih baik (Patil \& Kumar, 2014)

Dari beberapa hal di atas, maka perlu dilakukan sebuah penelitian yang bertujuan untuk mengetahui potensi baja Ni berbahan dasar bijih laterit sebagai material grinding ball dengan menggunakan metode peningkatan sifat mekanik dengan perlakuan panas cryogenic treatment serta pengaruh paduan kromium dan molibdenum terhadap sifat mekanik dan karakteristik struktur mikro baja Ni.

\section{METODE PENELITIAN}

Alat dan bahan yang digunakan pada penelitian ini yaitu baja nikel berbasis laterit, nitrogen cair, air, tabung vacuum, mesin bubut, mesin milling, EDM (Electrical Discharge Machine), furnace, alat uji kekerasan, alat uji 
abrasi, alat uji impak, seperangkat alat metalografi dan mikroskop optik.

Proses diawali dengan preparasi sampel meliputi pemotongan, pembubutan, milling, surface grinding dan pembuatan $V$ notch untuk membentuk sampel sesuai standar uji kekerasan, uji abrasi dan uji impak. Sampel kemudian dipanaskan pada temperatur austenisasi yaitu $950^{\circ}$ $\mathrm{C}$ selama 1 jam kemudian didinginkan (quench) pada media air hingga mencapai temperatur kamar lalu dilanjutkan dengan pendinginan pada nitrogen cair selama 10 menit, 60 menit dan 360 menit untuk mengetahui proses pembentukan fasa martensit optimal maupun austenite sisa terendah. Sampel kemudian dikeluarkan dari tabung berisi nitrogen cair dan didiamkan pada udara terbuka hingga mencapai temperatur kamar dan dilanjutkan dengan pemansan kembali (tempering) pada temperatur $200^{\circ} \mathrm{C}$ selama 1 jam.

Diagram alir proses penelitian ini ditunjukkan pada Gambar 1.

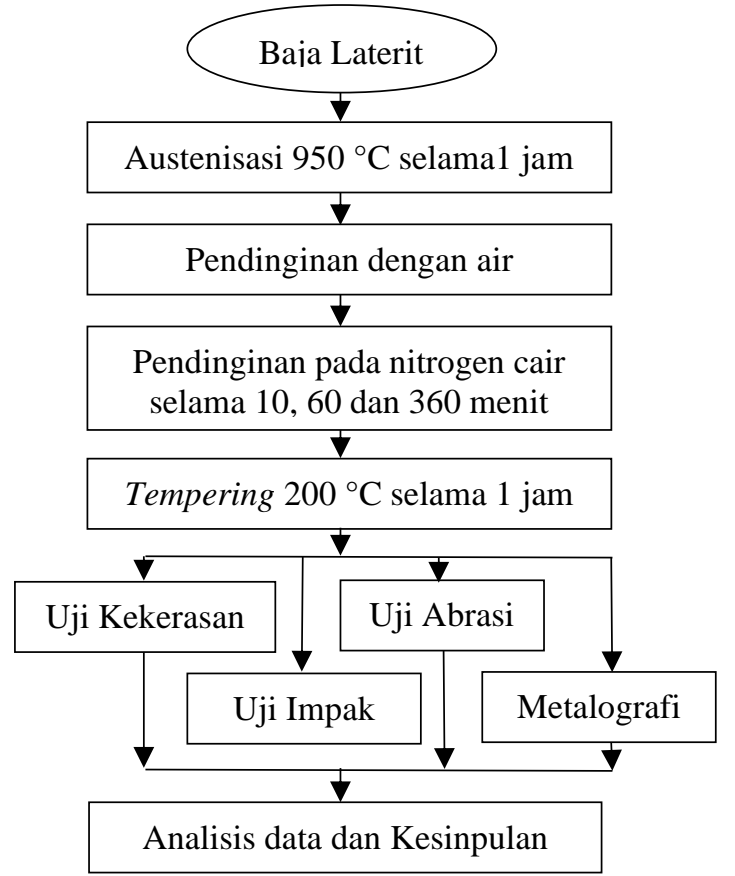

Gambar 1. Diagram alir penelitian

Sampel baja laterit yang telah diproduksi oleh P2MM LIPI yang digunakan pada penelitian ini dilakukan karakterisasi yaitu uji kekerasan dengan metode Rockwell $C$, uji ketahanan aus, uji impak dengan metode impak Charpy dan analisis metalografi baik sebelum maupun setelah dilakukan proses cryogenic treatment.
Uji kekerasan dilakukan pada sampel dengan ukuran $10 \times 10 \times 10 \mathrm{~mm}$ dengan indentasi menggunakan indentor kerucut intan. Sedangkan uji ketahanan aus atau abrasi menggunakan sampel berbentuk silinder pejal dengan diameter $35 \mathrm{~mm}$ dan tinggi $12 \mathrm{~mm}$. Pengujian menggunakan kertas ampelas \#120 dengan pembebanan sebesar $1 \mathrm{~kg}$. Pengujian impak menggunakan sampel dengan dimensi $10 \times 10 \times 55$ $\mathrm{mm}$ dengan takik berbentuk $\mathrm{V}$ dengan kedalaman $2 \mathrm{~mm}$. Pada pengamatan metalografi sampel mula-mula dilakukan preparasi yaitu grinding dengan kertas ampelas \#80 hingga \#2000 kemudian dilanjutkan dengan proses polishing mengguhakan pasta alumina $5 \mu$ hingga $0,1 \mu$ lalu dilakukan etsa dengan menggunakan larutan nital $2 \%$. Pengamatan metalografi dilakukan dengan menggunakan mikroskop optik dengan perbesaran $500 \times$.

\section{HASIL DAN PEMBAHASAN}

\section{Analisis Komposisi Kimia}

Tabel 1. Komposisi kimia sampel

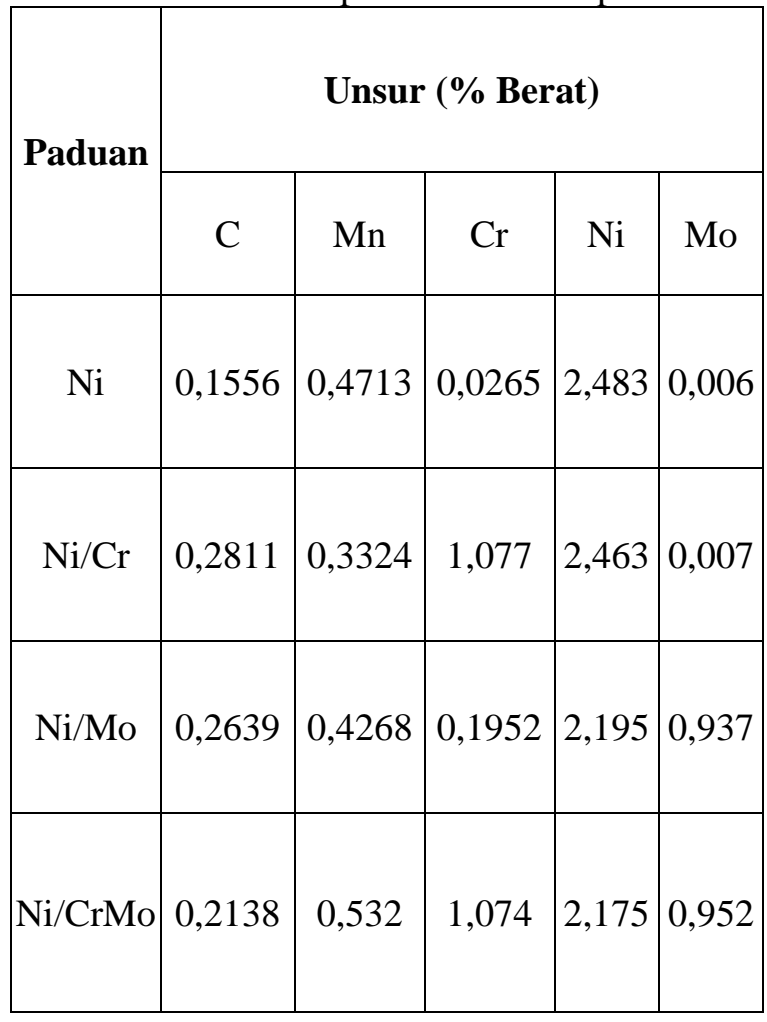

Pada Tabel 1 dapat dilihat perbedaan komposisi kimia dari sampel yang digunakan pada penelitian ini. Terdapat perbedaan yang mencolok 
pada kandungan $\mathrm{Cr}$ dan Mo dimana terdapat sampel yang tidak memiliki kandungan $\mathrm{Cr}$ maupun Mo (kode sampel Ni), dengan kandungan paduan $\mathrm{Cr}$ (kode sampel $\mathrm{Ni} / \mathrm{Cr}$ ), dengan kandungan Mo (kode sampel Ni/Mo) dan dengan kandungan $\mathrm{Cr}$ dan Mo (kode sampel Ni/CrMo). Variasi pemaduan ini dilakukan karena $\mathrm{Cr}$ dan $\mathrm{Mo}$ mampu meningkatkan kekerasan pada baja sehingga digunakan paduan kedua unsur tersebut. Selain itu, Cr dan Mo juga dikenal sebagai pembentuk karbida. Karbida yang memiliki kekerasan tinggi akan meningkatkan kekerasan baja (Totten G.E 2006).

\section{Analisis Metalografi}

Hasi pengujian metalografi ditunjukan pada Gambar 2, 3 dan 4. Pada gambar tersebut dapat diketahui bahwa struktur mikro yang dihasilkan yaitu martensit. Namun pada gambar struktur mikro tersebut juga masih terdapat austenit sisa.

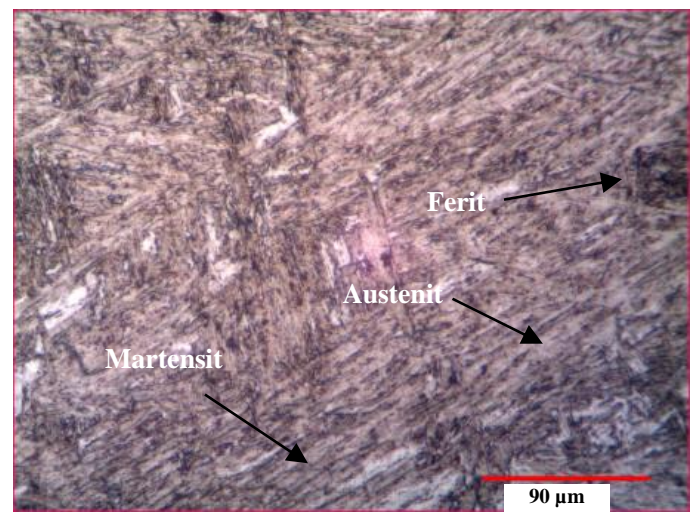

Gambar 2. Sruktur mikro waktu perendaman 10 menit

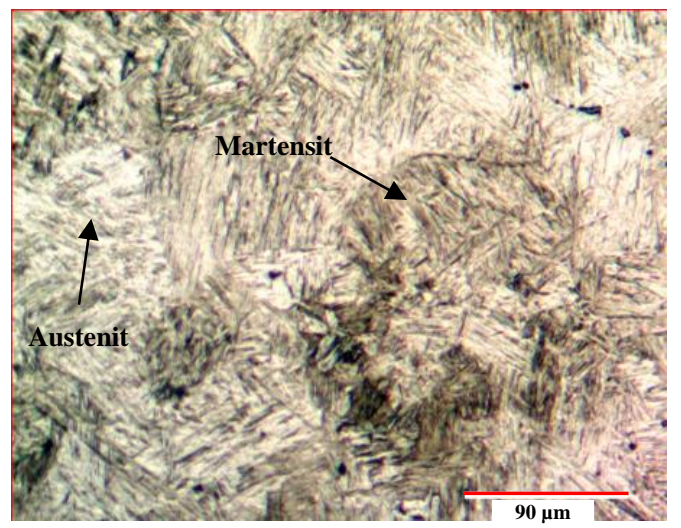

Gambar 3. Struktur mikro waktu perendaman 60 menit

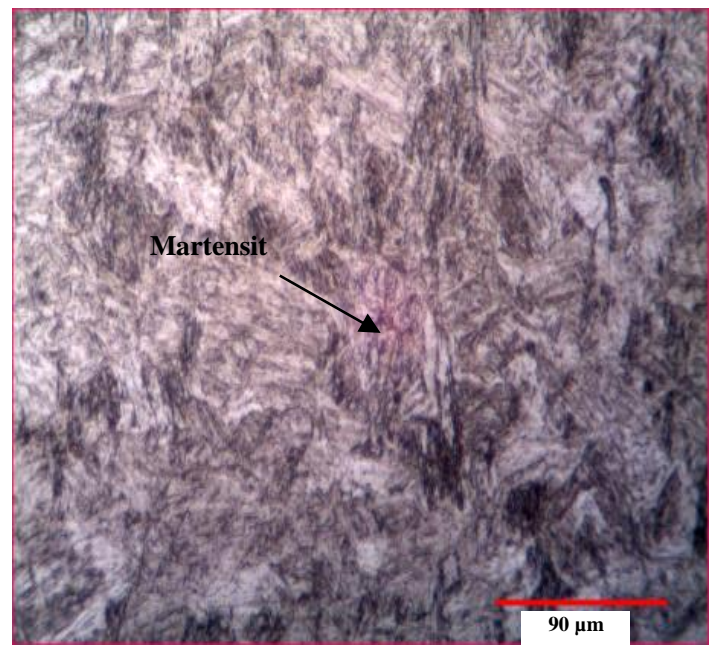

Gambar 4. Struktur mikro waktu perendaman 360 menit

Pada Gambar 2, 3 dan 4 dapat dilihat bahwa kerapatan atau persentase martensit yang terbentuk semakin banyak seiring dengan penambahan waktu perendaman yaitu 10 menit, 60 menit dan 360 menit. Dengan menggunakan perhitungan luas area menggunakan perangkat lunak komputer imageJ didapatkan hasil yaitu $90,519 \%$ fasa martensit pada waktu perendaman 10 menit, $91,488 \%$ fasa martensit pada waktu perendaman 60 menit dan $98,617 \%$ fasa martensit dengan perendaman 360 menit. Hal ini dikarenakan semakin lama waktu perendaman pada proses cryogenic treatment maka proses transformasi fasa austenit sisa menjadi fasa martensit terjadi lebih banyak sehingga akan menghasilkan fasa martensit yang lebih banyak. Persentase martensit yang semakin banyak akan meningkatkan kekerasan dan ketahanan aus dari material tersebut.

\section{Uji Kekerasan}

Pada Gambar 5 ditunjukkan grafik hubungan nilai kekerasan terhadap waktu perendaman pada setiap sampel. Grafik pada Gambar 5 menunjukkan bahwa kenaikan pada setiap sampel seiring dengan bertambahnya waktu perendaman yang dilakukan. Pada sampel Ni, $\mathrm{Ni} / \mathrm{Cr}, \mathrm{Ni} / \mathrm{Mo}, \mathrm{Ni} / \mathrm{CrMo}$ mengalami peningkatan kekerasan dengan waktu perendaman yang semakin lama dengan nilai kekerasan maksimum berturut-turut yaitu 33,$55 ; 43,18 ; 39,04$ dan 44,1 HRC. Semakin lama waktu perendaman dalam 
temperatur cryogenic maka akan semakin banyak austenit sisa yang bertransformasi menjadi martensit sehingga akan semakin banyak terbentuk fasa martensit dimana martensit memiliki kekerasan yang tinggi sehingga material akan semakin keras. Hal ini didukung dengan analisis metalografi yang telah dilakukan dimana fasa martensit bertambah seiring dengan bertambahnya waktu perendaman dalam cryogenic treatment.

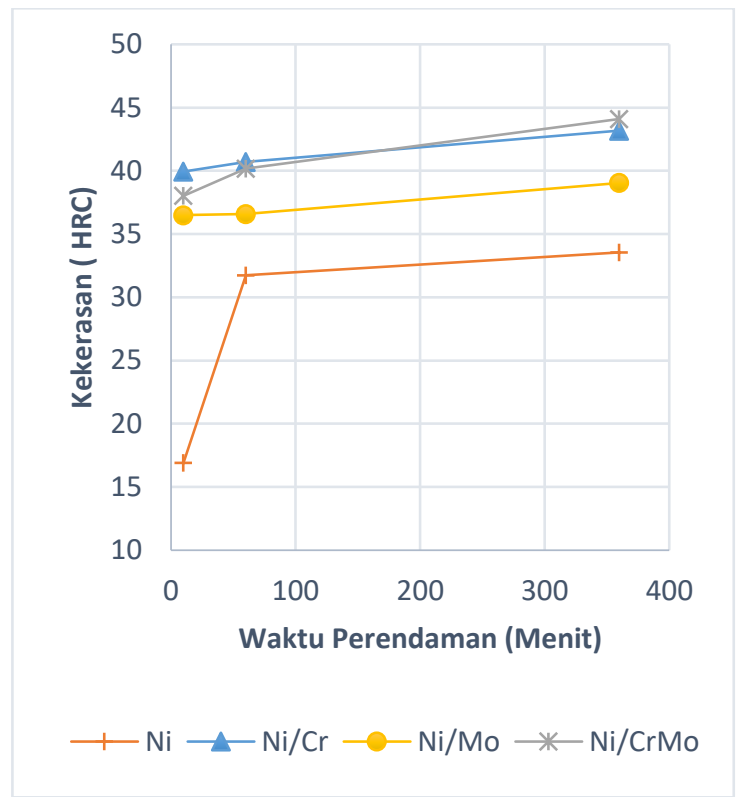

Gambar 5. Grafik hasil uji kekerasan

Hal tersebut meningkatkan kekerasan serta ketahanan aus dari material, namun setelah mencapai titik optimum semakin lama waktu perendaman kekerasan menurun seiring dengan menurunnya jumlah karbida dan keseragaman distribusi karbida (Amini, Akhbarizadeh, dan Javadpour 2012).

Pada Gambar 5 diketahui bahwa terdapat perbedaan kekerasan setelah dilakukan proses cryogenic treatment pada setiap perbedaan komposisi kimia pada setiap sampel. Sampel yang memiliki kekerasan paling tinggi yaitu sampel $\mathrm{Ni} / \mathrm{CrMo}$ sebesar 44,1 HRC pada waktu perendaman 360 menit dan sampel dengan kekerasan terendah yaitu sampel Ni. Hal ini menunjukan bahwa penambahan unsur $\mathrm{Cr}$ dan $\mathrm{Mo}$ pada baja $\mathrm{Ni}$ dapat meningkatkan kekerasan. Perbedaan nilai kekerasan yang terjadi pada perbedaan komposisi paduan Cr maupun Mo yaitu akibat terbentuknya karbida halus yang terbentuk selama proses cryogenic treatment karena unsur paduan $\mathrm{Cr}$ dan Mo merupakan unsur paduan yang memiliki sifat yang kuat dalam hal pembentukan karbida.

Varghese et. al (Varghese, Ramesh, dan Chakradhar 2019) pada penelitiannya menyatakan bahwa terbentuknya presipitat karbida merupakan hal yang juga mempengaruhi peningkatan sifat mekanik material setelah melalui proses cryogenic treatment. Presipitat karbida yang terbentuk menurunkan tegangan internal pada fasa martensit dan meminimalisir terjadinya micro-crack. Distribusi karbida yang seragam merupakan hal yang mempengaruhi tingginya kekerasan dan ketahanan abrasif yang terjadi (Varghese, Ramesh, dan Chakradhar 2019). Seyed Ebrahim Vahdat et al. pada jurnalnya mengatakan bahwa peningkatan waktu perendaman mengakibatkan peningkatan karbida sekunder yang akan berimbas pada penigkatan kekerasan (Vahdat, Nategh, dan Mirdamadi 2014).

\section{Uji Ketahanan Abrasif}

Pada Gambar 6 ditunjukkan hasil pengujian ketahanan aus yaitu hubungan antara ketahanan aus terhadap waktu perendaman cryogenic treatment pada setiap sampel.

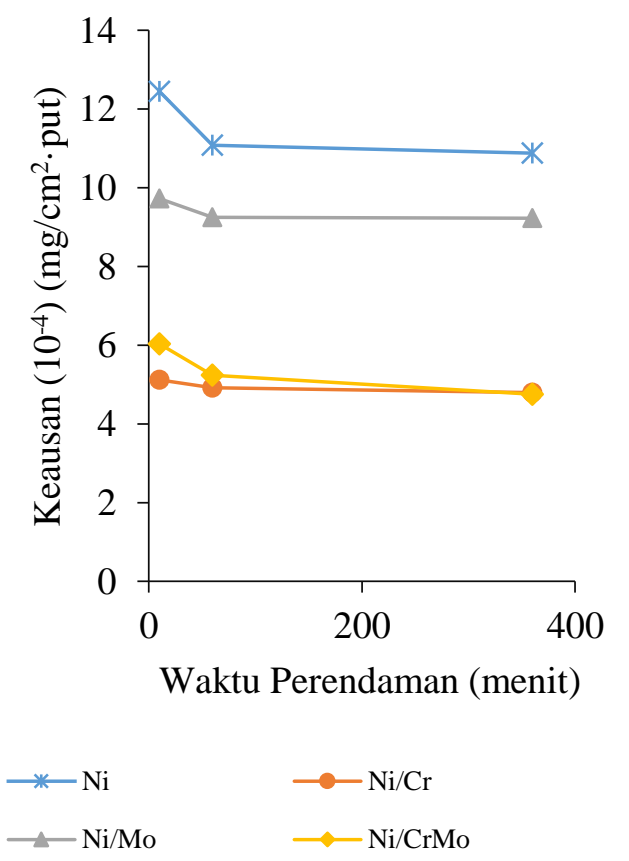

Gambar 6. Grafik hasil uji ketahanan aus 
Pada gambar tersebut dapat dilihat bahwa nilai keausan semakin rendah seiring dengan bertambahnya waktu perendaman yang dilakukan. Pada sampel Ni/CrMo terdapat penurunan keausan pada waktu perendaman 10, 60 dan 360 menit berturut-turut yaitu 0,000603, 0,000523 dan $0,000475 \mathrm{mg} / \mathrm{cm}^{2}$. put. Perubahan nilai ketahanan aus tersebut terjadi karena adanya peningkatan kekerasan dan terbentuknya fasa martensit. Nilai keausan terkecil pada sampel $\mathrm{Ni}$ adalah 0,001088 $\mathrm{mg} / \mathrm{cm}^{2} \cdot$ put, sampel $\mathrm{Ni} / \mathrm{Cr}$ adalah 0,000475 $\mathrm{mg} / \mathrm{cm}^{2} \cdot$ put, sampel $\mathrm{Ni} / \mathrm{Mo}$ adalah 0,000933 $\mathrm{mg} / \mathrm{cm}^{2} \cdot$ put dan pada sampel $\mathrm{Ni} / \mathrm{CrMo}$ adalah $0,000475 \mathrm{mg} / \mathrm{cm}^{2} \cdot$ put.

Pada Gambar 6 menyatakan bahwa terdapat perbedaan keausan pada setiap sampel pada setiap waktu perendaman cryogenic treatment. Hal ini menunjukan bahwa perbedaan komposisi kimia pada setiap sampel dapat mempengaruhi sifat ketahanan aus disetiap sampel. Keausan terkecil yaitu terdapat pada sampel dengan kandungan unsur paduan kromium dan molibdenum (sampel $\mathrm{Ni} / \mathrm{CrMo}$ ) yaitu sebesar $0,000475 \mathrm{mg} / \mathrm{cm}^{2}$.putaran. Ditinjau dari sturktur mikro yang dihasilkan bahwa struktur mikro paduan $\mathrm{Ni} / \mathrm{CrMo}$ memiliki persentase fasa martensit lebih besar dibandingkan dengan sampel lain. Hal tersebut memberikan pengaruh terhadap ketahanan aus dari sampel tersebut.

Ratia (Vilma Ratia 2016) menyatakan pada penelitiannya bahwa keausan dari suatu material dapat dipengaruhi oleh beberapa hal salah satunya adalah kekerasan. Material yang memiliki kekerasan yang tinggi akan cenderung memiliki nilai keausan yang lebih rendah dibandingkan dengan material yang memiliki kekerasan yang lebih rendah. Hal serupa ditunjukan pada penelitian ini yaitu pada setiap sampel yang telah melalui proses cryogenic treatment mengalami peningkatan kekerasan dan penurunan keausan. Sampel dengan kekerasan tertinggi sebesar 44,1 HRC dan juga memiliki keausan terendah sebesar $0,000475 \mathrm{mg} / \mathrm{cm}^{2}$.putaran. yaitu pada sampel $\mathrm{Ni} / \mathrm{CrMo}$ pada waktu perendaman 360 menit

Meng et al. (Meng, Tagashira, and Sohma 1994) pada penelitiannya menjelaskan bahwa ketahanan aus akan menjadi lebih baik dapat dicapai dengan meningkatkan waktu perendaman dalam proses cryogenic treatment. Hal ini dikarenakan adanya pembentukan karbida yang meningkatkan ketahanan aus material semaksimal mungkin. Selain itu transformasi fasa austenit sisa menjadi fasa martensit juga menyebabkan terjadinya cacat kristal seperti dislokasi dan twins yang juga mempengaruhi kekerasan dan ketahanan aus. Dr. Abbas A. Hussein et al (Husein Abbas 2012) dalam penelitiannya menggunakan proses cryogenic treatment pada baja karbon rendah juga menyatakan bahwa terjadi peningkatan kekerasan dan ketahanan aus setelah proses cryogenic treatment.

\section{Uji Impak}

Pada Gambar 7 yaitu grafik hasil uji impak yang menunjukkan hubungan antara waktu perendaman cryogenic treatment dengan energi yang diserap yang dinyatakan dalam Joule. Pada grafik tersebut menunjukkan bahwa adanya penurunan energi yang diserap pada sampel seiring dengan bertambahnya waktu perendaman pada proses cryogenic treatment. Penurunan energi yang diserap oleh sampel menyatakan bahwa ketangguhan dari sampel tersebut menurun. Pada grafik di atas sampel dengan ketangguhan terbaik yaitu pada sampel $\mathrm{Ni} / \mathrm{CrMo}$ pada waktu perendaman 10 menit dengan energi yang diserap sebesar 39,5 joule dan sampel dengan ketangguhan terendah yaitu pada sampel $\mathrm{Ni} / \mathrm{Cr}$ pada waktu perendaman 60 menit dan 360 menit dengan energi yang diserap sebesar 14 Joule.

Penurunan ketangguhan yang terjadi akibat dari adanya pertambahan persentase struktur martensit yang terbentuk seiring dengan bertambahnya waktu perendaman dalam cryogenic treatment. Semakin lama waktu perendaman pada cryogenic treatment maka akan semakin banyak austenit sisa yang bertransformasi menjadi martensit sehingga akan menyebabkan bertambahnya persentase martensit. Martensit bersifat getas sehingga dengan semakin banyak terbentuk martensit ketangguhan akan semakin menurun. 


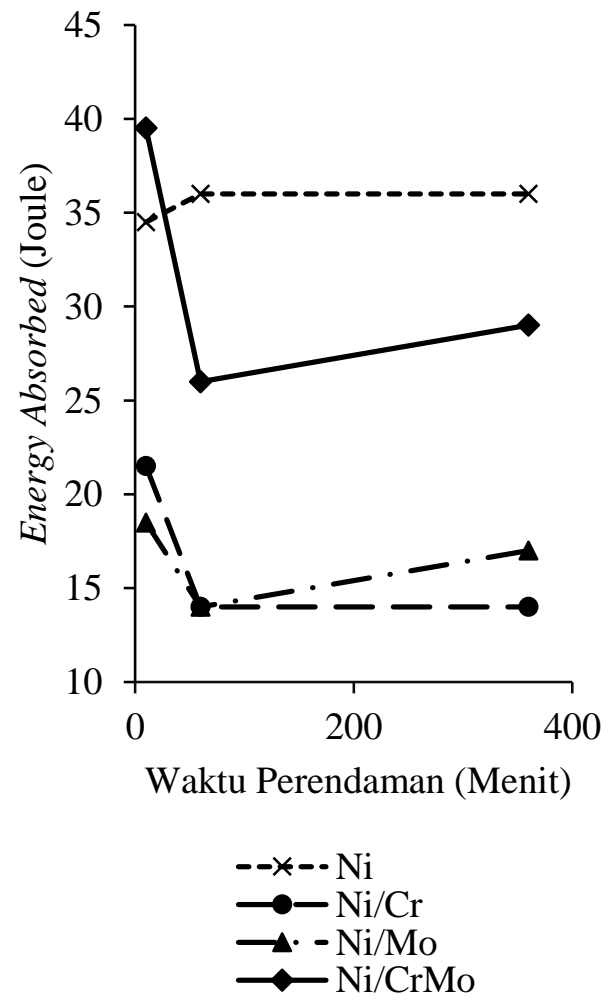

Gambar 7. Grafik hasil pengujian impak

\section{KESIMPULAN DAN SARAN}

Dari penelitian yang telah dilakukan pada baja berbasis laterit dengan perbedaan komposisi paduan $\mathrm{Cr}$ dan Mo yang dilanjutkan dengan cryogenic treatment dengan variasi waktu perendaman 10 menit, 60 menit dan 360 menit dapat disimpulkan bahwa komposisi paduan $\mathrm{Cr}$ dan Mo meningkatkan sifat mekanik dari baja Ni yaitu kekerasan, ketahan aus dan ketangguhan. Kekerasan, ketahanan aus dan ketangguhan terbaik terdapat pada sampel $\mathrm{Ni} / \mathrm{CrMo}$ secara berturut-turut yaitu sebesar 44,01 HRC, 0,000475 $\mathrm{mg} / \mathrm{cm}^{2}$.putaran dan 39,5 Joule. Waktu perendaman pada proses cryogenic treatment dapat mempengaruhi sifat mekanik dari baja $\mathrm{Ni}$. Semakin lama waktu perendaman maka kekerasan dan ketahanan aus dari sampel akan semakin meningkat namun menurunkan ketangguhan. Nilai kekerasan dan ketahanan aus terbaik yaitu sebesar 44,01 HRC dan $0,000475 \mathrm{mg} / \mathrm{cm}^{2}$. putaran pada waktu perendaman 360 menit dengan nilai ketangguhan terbaik yaitu sebesar 39,5 Joule pada waktu perendaman 10 menit. Struktur mikro yang dihasilkan pada penelitian ini yaitu didominasi dengan struktur martensit dengan persentase kurang lebih $90 \%$.

Saran untuk penelitian selanjutnya yang mungkin dapat memperbaiki penelitian ini yaitu pada proses cryogenic treatment menggunakan variasi waktu yang lebih lama untuk mengetahui titik optimum dari peningkatan sifat mekanik yang dapat terjadi.

Komposisi unsur paduan perlu dilakukan variasi yang lebih luas untuk mengetahui pengaruh yang akan terjadi pada sifat mekanik. Perlu dilakukan pengamatan menggunakan metode lain untuk mengamati karbida yang mungkin terbentuk dan mempengaruhi sifat mekanik yang dihasilkan.

\section{UCAPAN TERIMA KASIH}

Penulis mengucapkan terima kasih kepada Pusat Penelitian Metalurgi dan Material LIPI yang telah mendanai penelitian ini. Ucapan terima kasih juga disampaikan kepada seluruh peneliti dan juga teknisi yang ikut serta membantu dalam rangka menjalankan dan menyelesaikan proses penelitian dan penulisan makalah ini.

\section{DAFTAR PUSTAKA}

Amini, Kamran, Amin Akhbarizadeh, dan Sirus Javadpour. 2012. "Investigating the effect of holding duration on the microstructure of 1.2080 tool steel during the deep cryogenic heat treatment." Vacuum 86 (10): 1534-40. https://doi.org/10.1016/j.vacuum.2012.0 2.013.

Herbirowo, Satrio, dan Bintang Adjiantoro. 2016. "Pengaruh Perlakuan Panas Terhadap Struktur Mikro dan Kekuatan Mekanik Baja Nikel Laterit." Widyariset 2 (2): 153-60.

Husein Abbas. 2012. "Effect of Cryogenic Treatment on the Properties of Low Carbon A858." Journal of Engineering 18 (7).

Meng, Fanju, Kohsuke Tagashira, dan Hideaki Sohma. 1994. "Wear resistance and microstructure of cryogenic treated Fe-1.4Cr-1C bearing steel." Scripta Metallurgica et Materiala 31 (7): 86568. https://doi.org/10.1016/0956- 
716X(94)90493-6.

Patil, P I, dan Bimlesh Kumar. 2014. "Deep Cryogenic Treatment of Alloy Steels : A Review." International Journal of Electronics, Communication \& Soft Computing Science and Engineering 2 (8).

Sabih, Amar, Peter Radziszewski, dan Ivan Mullany. 2017. "Investigating grinding media differences in microstructure, hardness, abrasion and fracture toughness." Minerals Engineering 103104: 43-53. https://doi.org/10.1016/j.mineng.2016.0 8.014 .

Totten G.E. 2006. "Steel Heat Treatment Metallurgy and Technologies." Steel Heat Tratment Handbook.

Vahdat, Seyed Ebrahim, Said Nategh, dan Shamsoddin Mirdamadi. 2014. "Effect of microstructure parameters on tensile toughness of tool steel after deep cryogenic treatment." International Journal of Precision Engineering and Manufacturing 15 (3): 497-502. https://doi.org/10.1007/s12541-0140363-4.

Varghese, Vinay, M. R. Ramesh, dan D. Chakradhar. 2019. "Influence of deep cryogenic treatment on performance of cemented carbide (WC-Co) inserts during dry end milling of maraging steel." Journal of Manufacturing Processes 37 (April 2018): 242-50. https://doi.org/10.1016/j.jmapro.2018.1 1.030 .

Vilma Ratia. 2016. Behavior of martensitic wear resistant steels in abrasion and impact wear testing conditions. Tribologia dissertation. Vol. 34. 